\title{
The Impact of Socioeconomic Characteristics on Older Employees' Willingness to Continue Working in Retirement Age
}

\author{
Frank Micheel, Juliane Roloff, Ines Wickenheiser
}

\begin{abstract}
This article explores whether and to what degree information on the socioeconomic status - measured by professional status and disposable household income - allows making reliable statements on the willingness to remain in work in retirement age. These observations are controlled for professional and individual characteristics. The data basis is constituted by the study entitled "Continuing in employment in pensionable age" with $N=1,500$ dependent employees aged from 55 to under 65. Logistic regressions show that the socioeconomic status makes a statistically-significant contribution towards explaining the willingness to continue in employment: In comparison to employees with a lower or medium professional status, those individuals who have a high professional status tended to be significantly more willing to remain in working life for longer. There is a negative connection between the disposable household income and the willingness to remain in employment in retirement age. The significant effects that were found are however restricted to the women in the study.
\end{abstract}

Keywords: Demographic ageing $\cdot$ Retirement age $\cdot$ Labour market $\cdot$ Extended working life $\cdot$ Socioeconomic status · Role theory · Continuity theory · Life course perspective

\section{Introduction}

The future demographic changes within the population in Germany will gradually influence the supply side on the labour markets. As a result of the decades of low fertility levels, there will be a long-term decline in the size of the potential working population as fewer and fewer young people advance into working life, whilst at the same time an expanding group of older workers leaves the labour market. The dynamics of this shift will probably be most pronounced in the period between 2020 and 2030, when the high-fertility cohorts of the 1950s and 1960s, the so-called baby-boomers, successively retire (Höhn et al. 2008; Börsch-Supan/Wilke 2009). 
The predictable ageing of society has for example consequences for pay-as-you-go pension systems in the sense that the relation between younger and older people will develop for the benefit of the older and, as can presently be seen, greater burdens will be imposed on the young working-age population.

A variety of pension reforms aim to adjust the ratio between contributors and beneficiaries. The legal amendments to the statutory retirement age, together with alterations in labour law, should be particularly emphasised here. Whilst a trend towards early retirement was promoted between the 1970s and the 1990s in order to "make space" for the coming generations in the working world, a reversal in this trend has been developing since the 1990s (Backes/Clemens 2003: 43; Wübbeke 2005: 9-29; Bäcker et al. 2009: 46-50; Deutscher Bundestag 2006: 84-86). The fact that the opportunity is (still) being taken to retire before reaching the regular age limit is proven by taking a look at the retirement statistics. In 2007, almost half of the respective pension cohort, which is a considerable share of recently-retired individuals, had retired with financial reductions (Brussig 2010b). The Act to Adjust the Standard Age Limit to Demographic Developments and to Strengthen the Financial Foundation of Statutory Pensions Insurance (Gesetz zur Anpassung der Regelaltersgrenze an die demografische Entwicklung und zur Stärkung der Finanzierungsgrundlagen der gesetzlichen Rentenversicherung), also known as "Retirement at $67^{\prime \prime}$, points to the future in that such an early departure from working life, if possible at all, will entail considerable long term financial burdens. Therefore, there will be growing legal and economic pressure on the future working population to work longer.

There has been little discussion in Europe, and particularly in Germany, on the future extension of the working phase beyond the age of 65 (Komp et al. 2010). This is understandable in the sense that these considerations will only become more significant in connection with "Retirement at 67". Considerations to date have tended to focus on how early retirement could be achieved in social, political or economic terms (e.g. Bäcker et al. 2009). Also, the current figures on earning conduct, differentiated by age, show that employment rates fall markedly from the age of 55 , and that the fall becomes more dynamic from the age of 60 (Fig. 1).

In the context of "Challenges and Perspectives in an Ageing Society", one of the main research areas of the Federal Institute for Population Research, it should be explored with regard to the potential of older people to be available on the labour markets whether in addition to the mentioned legal constraints and resultant economic ones, persons would also be willing to work beyond the age of 65 (the current retirement age for receiving an unreduced old-age pension) on a voluntary basis. As a part of "active" or "productive" ageing (Künemund 2006), voluntary willingness to continue in employment after officially withdrawing from the working world is likely to become still more significant for the future. This is justified not lastly by the fact that today's elderly differ considerably from yesterday's with regard to their state of health, living conditions or financial security. Hence, today's elderly on average already have many more resources available which they can use for active, pro- 
Fig. 1: Employment rates of 55-year-olds and older by age, 2008

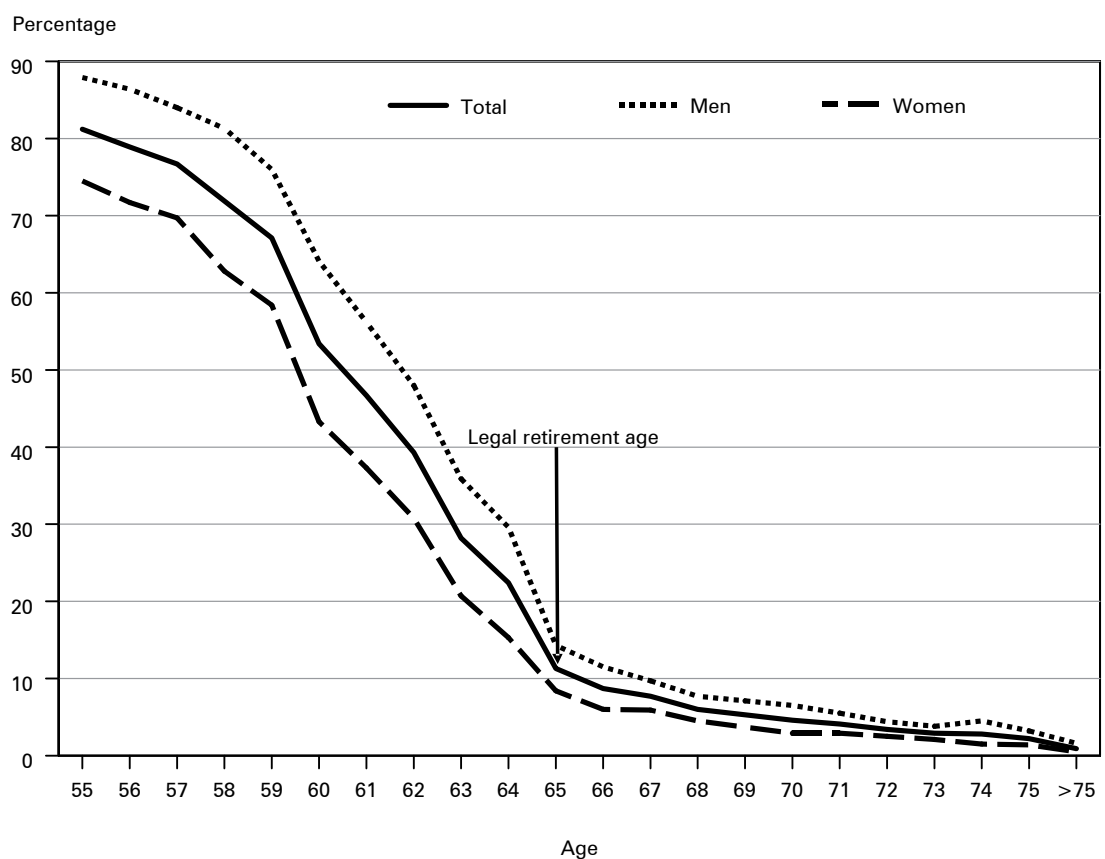

Source: Statistisches Bundesamt, own calculations

ductive ageing ${ }^{1}$ (Künemund 2006: 292-296; Deutscher Bundestag 2006). Moreover, further improvements in the resources available, as well as in living conditions, are anticipated for "tomorrow's elderly" (Mai 2003: 233-240).

The demographic and pension law developments - increasing life expectancy and earlier retirement - have so far interacted to help many older people in Germany to have an average time phase of almost 20 years to dispose of freely, based on the average retirement age. The greater part of this gained time is spent in good health (Kruse/Lehr 1990: 81-82; Klein/Unger 2002; Deutscher Bundestag 2006: 48-49; Deutsche Rentenversicherung Bund 2009: 137). The increased active time constitutes a potential that is relevant to society. Taking advantage of this potential would considerably benefit not only society, but also the individuals themselves if they

1 The term "productive ageing" should be defined more broadly in this connection than the economic point of view of productivity. Productive activities in old age encompass in general terms all activities which society considers to be worthwhile (e.g. volunteering or informal long-term care services provided within the family), albeit the limits between individual concrete activities are disputed (O'Reilly/Caro 1995: 40-42; Caro 2008: 76-78). It is for instance disputed whether an activity which serves to maintain individual independence is referred to as productive (Tews 1996; Lehr 2000). 
age actively, in good health and with a high level of satisfaction with life. ${ }^{2}$ In view of the demographic development, the group of "young old" individuals - a group of people who have (largely) concluded their professional careers, but whose lives are lived in an independent manner in which they take responsibility for themselves (Moen 2003: 270) - will be much larger in the coming years, and indeed will actually become the largest group in the population, when the baby-boomers (birth cohorts of the 1950s and 1960s) advance into this age (Statistisches Bundesamt 2009).

This article explores whether a fundamental willingness exists among the older working population to remain employed in retirement age and what reasons can be stated for this willingness. To answer these questions, first of all the current state of knowledge is reflected and the theoretical approaches will be discussed (sections 2 and 3). On this basis, the hypotheses presented will be empirically examined after the data basis and the initial descriptive findings have been presented (sections 4 and 5). The final section provides a critical discussion of the findings (section 6).

\section{State of research and determinants of continuing in employment after retirement}

In connection with the extension of the active working phase, the phenomenon of bridge employment is illustrated in a growing number of surveys, largely in the US literature (e.g. Feldman 1994; Gobeski/Beehr 2009; Pengcharoen/Shultz 2010). The term "bridge employment" is understood as taking up/re-entering a paid activity after the person has officially withdrawn from working life. This may be either the continuation of the previous career-related occupation in the same or another organisation, or an activity in another professional field. The person can work as an employee or self-employed person irrespective of receiving a partial or full pension. This is hence a phase between the professional career and complete withdrawal from working life on grounds of age (Doeringer 1990; Feldman 1994: 286). This phenomenon has been discussed in a growing body of literature in the USA since the 1990s, given that the transition from working life to complete retirement constitutes more the exception than the rule and the paths from the world of work into retirement have become increasingly varied and complex (e.g. Ruhm 1990; Szinovacz 2003 for the USA and Engstler 2006; Radl 2007 for Germany). This phenomenon and the underlying mechanisms are not directly transferable to Germany since the labour market and pension law provisions in Germany are very different from those in the US. The question of whether a similar trend will emerge for the labour markets in Germany remains open at present. Nevertheless, a slight increase in employment in pensionable age has been observed in recent years. Initial analyses of microcensus

2 This statement requires however a differentiated consideration. Empirical investigations indicate that older people who continue to be active in retirement tend to be healthier (e.g. Zhan et al. 2009; one finding of the study was that continuing in employment when retired has a positive impact on the state of health). This should however be viewed cautiously when it comes to deriving causalities from these statistical correlations. 
data indicate that a person's profession plays a major role in this respect. Particularly in low-skill service occupations, continuing in employment beyond the age of 65 seems to be predominant (Brussig 2010a/c).

The lion's share of the investigations of the factors influencing the willingness to continue to work in pensionable age deals with the actual retirement conduct (for a comprehensive overview see Wang/Shultz 2010). Retroactively, it was possible to deduce motives and intentions regarding retirement conduct from the actual conduct. Research on the intentions or a general willingness to continue working in old age, when most other people are already retired, have been relatively rare so far (Shacklock et al. 2009: 80).

The idea of analysing the intentions of continuing in employment in retirement age dates back to the work of Beehr (1986), who stresses that the analysis of the retirement process should not be restricted to actual retirement, but should start before that. Retirement is said not to be understood as a one-off, discrete event, but as a sequence of different phases (from tendency towards retirement via deciding for retirement, through to actual implementation), depending on personal and contextual factors. The consideration of the whole process seems especially relevant since e.g. rather the fundamental preference towards retirement than the actual act enhances the explanation (Beehr 1986: 46).

In addition to old age, the financial situation and the state of health are generally regarded as constituting the most important determinants of the transition into retirement. A good state of health or an adequate disposable income enables individuals to retain control of their decisions with regard to the time of retirement (e.g. Moen 2003: 276; Taylor/Doverspike 2003: 62-65). By contrast, a poor state of health may entail the decision to discontinue working. A low income can constitute a motive for the individual to delay retirement, for instance for fear of poverty in old age which might be caused because of a career interruption or of below-average lifetime earnings. But what might the decision with regard to exercising a vocational activity look like if the state of health were to be good, or at least adequate? What preferences do persons in employment with a higher income have with regard to the time of retirement? What significance attaches in this context to the characteristics of the enterprise or to regulations applying within the pension system?

The possible determinants of willingness to remain in working life for longer can be sub-divided into three levels: the political-social, the company, and the individual levels (Komp et al. 2010). This article focuses on the latter two levels, whilst the political level is only to be briefly outlined in the next section.

\subsection{The development of the institutional framework and its consequences for retirement preferences}

The intention, the desire, or the willingness of employees to extend the active working phase beyond the statutory retirement age when approaching retirement is placed at the beginning of the retirement process. There may however also be a reciprocal relationship between the desire for and the realisation of employment in pensionable age. The practice of retiring older employees caused by the introduc- 
tion of flexible age limits in the context of the pension reform in 1972, and hence the desire to retire earlier than previously provided by pension law, appeared to be a kind of societal consensus. Early retirement was not merely tacitly tolerated, but indeed widely accepted by the players affected on the labour markets, employers and employees as well as their representatives, especially since this practice was promoted by the government, either by measures under the labour market law or by the pensions policy (Bäcker et al. 2009: 46-50; Deutscher Bundestag 2006: 79-81). This general trend can however be socially differentiated, so that one may not speak of the desire to retire:

"We can now presume that two different cultures have formed at the end of a working life: workers who can express themselves in their work and still have the requisite skills, energy and health would like to work for a long time, frequently longer than until pensionable age. Others who have little control and who suffer from health problems would prefer to invest their remaining energy in the new freedoms offered by leaving work early." (Deutscher Bundestag 2006: 80).

This alleged polarisation can however be explained if the remaining life expectancy is taken into account. Anyone whose health is restricted will tend to find themselves in the latter group and enjoy their relatively short remaining lives in retirement, whilst the first group sees a possibility to still realise themselves in working life (Deutscher Bundestag 2006).

This article links to the aspects put forward here, and investigates the degree to which the intentions to remain in employment in retirement are influenced by the company or individual framework.

\subsection{Vocational and organisational characteristics}

Vocational and organisational frameworks exert a strong influence on the decision on the time of retirement, since many aspects are beyond the control of the individual.

A recent survey of the intensions of elderly employees to remain in working life for longer comes from Shacklock et al. (2009). The analyses especially discussed the potential influences exerted by vocational characteristics on the intention to remain in work for longer: perceived autonomy, personal relationships at work, working environment, flexibility as well as commitment to the job. The target group of the questionnaire was employees aged 50 or older who worked in a major Australian public organisation. It was possible to ascertain that the characteristics "relative significance of work", "flexibility" and "interests outside work" exerted a statistically-significant influence on the intention to remain employed for longer. There were major differences here between the genders. The intentions of the male respondents were influenced by the characteristics "relative significance of work" and "interests outside work". The characteristics "personal relationships", "perceived autonomy", "flexibility" and "interests outside work" played a major role for the female respondents. 
Further findings come from an empirical study carried out in the Netherlands (van Dam et al. 2009). The authors found that the respondents tended to want to retire later if they perceived their working environment as challenging and pleasant.

Strenuous working conditions such as stress, hard physical or repetitive activities, or shift work, can have a major impact on the state of health, and hence markedly restrict latitude for decision-making with regard to leaving work. Empirical surveys indicate that early retirement is frequently related to high workplace burdens and resultant health complaints. Especially age-related complaints emerge from the cumulative strains of a person's previous working life (Wübbeke 2005: 44-49). In the discussion on health strains, it is necessary to distinguish by occupations or levels of skill, while selection effects on the labour markets are not being ruled out. The tendency is for the (health-relevant) work strains not to be so pronounced in highly-skilled occupations, whilst activities requiring a lower level of skill frequently entail significant physical strains (Bäcker et al. 2009: 218-220; Blekesaune/Solem 2005: 6-11).

The importance of the perceived quality of work and of the job itself for the decision on retirement is shown by the survey carried out by Siegrist et al. (2007). On the basis of the Survey of Health, Ageing and Retirement in Europe (SHARE), the authors find that a poor psychological quality of work has a significant connection with the intention to withdraw from the labour market earlier. ${ }^{3}$ Comparable results are reached by Blekesaune and Solem (2005), but they were able to find genderspecific differences in their analyses. Men in occupations with restricted autonomy retired earlier than women in comparable occupational positions. Potential explanations given by the authors were that, firstly, men in general might have a stronger preference towards autonomy than women. Furthermore, also in this occupational segment, the working biographies of men were much less frequently characterised by interruptions than those of women, so that men in these positions were in a better financial position to afford to exit working life than women were. Finally, connections between a low occupational status and poor health might also be vital when deciding to retire sooner. This presumption could be derived from the fact that men in lower occupational positions are more frequently in a poor state of health than men at the higher levels within a company, and hence tend to receive disability pension benefits (Blekesaune/Solem 2005: 19-20.).

In addition to work characteristics as a factor potentially influencing retirement, organisational characteristics also exert an influence on elderly workers' retirement conduct. The decision whether to replace an older employee with a younger one is fundamentally subject to economic cost-benefit calculations. This calculation has become distorted in company practice by the subsidies which are provided for retiring the elderly (Wübbeke 2005: 61-69). The size of the enterprise might play a relevant role in this context. This characteristic frequently appears to be connected with age discrimination, something which appears to be more common in larger

3 Indicators of a low psychological quality of work were: Jobs with relatively taxing requirements, combined with low levels of control, as well as an imbalance between a high level of performance and a relatively low level of rewarding (Siegrist et al. 2007: 63). 
companies than in small and medium-sized ones. Placing older workers at a disadvantage manifests itself for instance in an ageist recruitment policy or in poorer prospects for promotion within the organisation. Older, mostly less well qualified employees are also at a disadvantage vis-à-vis their younger colleagues when it comes to in-company further and advanced training (Deutscher Bundestag 2006: 78, 105-107.). Equally, more comprehensive staff adjustments took place in larger enterprises in the 1980s/90s which were induced by tougher international competition or through the dying out of industrial manufacturing sectors. In the context of a general company strategy which aimed to reduce existing staff levels, older employees had much poorer prospects to remain in the enterprise in comparison to their younger colleagues (Bäcker et al. 2009: 169 and 179; Deutscher Bundestag 2006: 78; Feldman 1994).

The following connection can be presumed to exist when considering the average weekly working hours: The lower the number of weekly working hours, the less strenuous is the work, and the more likely older employees are to be willing to continue to work in retirement. Surveys using the data of the Socio-Economic Panel (SOEP) appear to support this connection: Larger numbers of hours worked per year were also connected to higher rates of people leaving work (Bäcker et al. 2009: 190 and 197).

Previous unemployment means for the individual not only an interruption in income, but also a loss of pension entitlements and thus also lower pension payments to be anticipated. Anyone experiencing an interruption in their working careers may hence see themselves as being forced by economic constraints to continue to work beyond the previous statutory retirement age.

The length of time in the company might also influence the willingness to continue in employment in retirement age. This aspect can be explained in connection with age-specific regulations on industrial safety and the situation of older workers on the labour market. Older employees have usually worked in the company for longer times than younger ones and thus enjoy better protection against dismissal. If, however, they lose their jobs, their prospects of finding a new job are much less favourable than those of their younger competitors (Deutscher Bundestag 2006: 64). Together with the higher labour market risk of older employees and a shorter job tenure one may therefore presume that such employees feel greater pressure to extend their working lives, and hence would show greater willingness. A further argument in favour of the presumed connection is that because of the wide spread of seniority-based payment in Germany, wages and salaries increase as people remain in a company for longer, and persons in employment who have not yet been in the company for so long will be more committed in order to receive these increases in income. These deferred compensations are to be understood as parts of an incentive scheme to stay in a company for longer since the employer implicitly offers a secure job to the employee. (Franz 2003: 58-59; Lazear 1979). 


\subsection{Individual characteristics}

Results from the empirical research on remaining employed in retirement permit one to presume the existence of a basic pattern: People who are still in work generally have the following characteristics: They are male, healthy, have a higher level of education and more assets, and are younger than retirees who are no longer in work (summed up in Pleau 2010: 270-272).

In relation to the characteristic of age, we presume a negative influence exerted on the willingness to continue in employment: The higher the age, the closer one is to the phase of retirement, and hence the lesser the willingness to continue in employment when retired (e.g. von Bonsdorff et al. 2009). Older employees observe the fall in their physical energy, as well as in cognitive skills, with the consequence that they tend to opt less to continue in employment in pensionable age (Wang/Shultz 2010: 185). Furthermore, age is positively related to claims on the pension system (under the condition that the individual indeed acquired entitlements through employment). Further, old age expresses a social norm which states that the status of "retiree" is reserved for the elderly (Adams et al. 2002: 128). There are however also surveys which weaken the above argument. For instance, Ekerdt et al. (2000: 5) critically state that old age is only a rough indicator to describe closeness to retirement. Hence, the perceived proximity to retirement would be included as a more suitable variable. This can be derived from the difference between biological age and anticipated retirement. On the other hand, empirical studies by Atchley and Robinson (1982) show no significant influence exerted by the time distance to retirement on attitudes towards retirement. In this respect, these results - even if they were not to reflect actual retirement conduct - would lead to a certain doubt as to the objection of Ekerdt et al. (2000: 5).

The connection between retirement conduct and gender, which was already described in section 2.2, is also a relevant question. Central aspects are the attribution of social roles, as well as the resultant consequences for the different career biographies. According to the traditional perception of roles of women and men (male breadwinner model), there would be unambiguous differences between the genders with regard to the transition into retirement. This is specifically caused by the gender-specific biographies. In the understanding of the "normal biography", men leave full-time employment when entering working life early, with small or only brief interruptions and a normal age-related departure from the working environment, however "normal" is defined. In contrast, women show more frequent interruptions in their career biographies, indicating a later start of employment, interruptions caused by child-raising or care-taking, as well as considerable phases of part-time work. Furthermore, it is largely women in the midst of life who carry out long-term care of their parents or parents-in-law, causing further difficulties when it comes to labour market integration issues. As a consequence of these aspects, considerable financial disadvantages can be anticipated vis-à-vis men when it comes to safeguarding a livelihood in the life phase after retirement (Al/mendinger 1994; Clemens 2006). This leads in turn to a situation in which older female employees may find themselves forced to remain in the earning process for longer than men 
of the same age for economic reasons. It should also be taken into consideration that a connection may be presumed to exist between retirement conduct and the time of relevant family events (in this case having children). In empirical analyses carried out by Hank (2004), two theoretically possible variants were compared and tested: Firstly, because of their cumulated work disadvantages it is conceivable that mothers tend to delay their retirement to later in life in order to catch up on pension entitlements. It is however also possible that mothers retire earlier if they only had a weak bond with their careers. This variant is linked to the "male bread winner" role model and that financial security is provided by the male spouse. On the basis of the data of the SOEP, it has been shown (for Western German women) that having children tended to postpone rather than bring forward the transition into retirement. This connection is amplified if the first child is born later or if mothers work during the first years of child-raising (Hank 2004).

However, gender-specific views of the individual significance of work may also be relevant for the desire to continue in employment. Men may attach significance to aspects such as power, the concept of performance, financial aspects or independence. Women, by contrast, appear to concentrate more on social connectivity (Talaga/Beehr 1995: 16-17; Mor-Barak 1995: 328-329). Depending on the framework which they encounter in their working world, the active working phase may be longer or shorter.

When taking a look at the state of health, it should be observed that the inclination towards work falls considerably with a poor state of health or with a low level of satisfaction with the state of health. A poor state of health is generally associated with a fall in ability to work. One may presume that the willingness to continue in employment in pensionable age falls if the persons in employment are in a poor state of health or are dissatisfied with their state of health. Anyone who no longer feels able to work for health reasons will take up the next available opportunity to retire early (summaries of the relevant literature can be found for instance in von Bonsdorff et al. 2009: 84; Bäcker et al. 2009: 190-191 and 222-232). A good state of health is likely to be a necessary, but not a sufficient condition for extending one's life working time. A good state of health does make it possible to continue one's professional career until the official retirement age; it is however also conceivable that the individual opts to cease working as early as possible in order to enjoy retirement as long as possible in good health and with a good financial security (Ekerdt 2009: 475).

Whether an individual plans to retire or to work on does not however always depend solely on his/her own preference when it comes to retirement, but is frequently to be understood in an interplay with the career biography of the spouse. In this respect, willingness to continue to work at retirement age also needs to be observed in connection with partnership status. This aspect took on significance (and is highly likely to continue to gain significance) in view of the past increases in the employment of married women: Two incomes from employment, two pension incomes and two states of health more and more frequently have to be taken into account when determining the time of retirement (e.g. Drobnič/Schneider 2000; Pienta/Hayward 2002). Empirical studies using the data from the SOEP support the 
presumption that there is a tendency towards retiring together. This study differentiated according to whether both partners are working, or only one of the two (Blau) Riphahn 1999). Married women appear to basically orientate their retirement time towards that of their husbands rather than vice versa (Drobnič/Schneider 2000). In a study by van Dam et al. (2009) among older Dutch workers (aged 50 or more), the question of intensions to retire early were explored. It emerged that persons intention to retire early indeed relates to their partners intentions regarding retirement who felt a pressure from their partners to leave work earlier indeed intended to retire early. Beyond partnership status, it is therefore important to learn how high the quality of the partnership is and how high the probability is to synchronise the respective careers. The age difference between the partners also plays a major role in this context. Men who are much older than their wives tend to delay their retirement (Drobnič/Schneider 2000).

Empirical studies on retirement in connection with socioeconomic characteristics tend to focus on the characteristics of income, education and last vocational status prior to retirement. It emerges in a comprehensive literature analysis by Brown and colleagues (1996) that no uniform picture prevails with regard to connections between social status and retirement conduct. This may be the case because the surveys which were consulted used different operationalisations of social status. Despite the different results that were found, however, it was also possible to find common features. It was thus shown that retirement conduct is clearly connected to the previous occupational status. Leaving work later appears to be linked to greater satisfaction with the current occupation (Brown et al. 1996: 181-182). These findings were also revealed in other surveys. In a survey by Flynn (2010), the author uses various factors to carry out a typologisation, and distinguishes employees who are approaching pensionable age into "haves" and "have-nots". The first group is characterised by a high degree of autonomy in work and a secure pension income. This group is therefore able to decide relatively freely when they retire. By contrast, the latter group does not have such options. They are pushed into or out of the work process depending on the situation on the labour market. The author goes on to state that the group which is able to decide freely on leaving work tends to delay retirement more than those older workers who do not have any options (Flynn 2010: 317).

Supported by empirical findings, a negative connection can be expected to exist between the amount of disposable income and willingness to continue in employment when retired (Beehr et al. 2000: 207-208). Households with a higher disposable income are financially better prepared for retirement, and hence enjoy greater freedom than those with a lower income when determining the time of retirement. Also, reductions which can be anticipated when it comes to retiring earlier than provided for by law are likely not to exert too strong an influence on those persons' decisions, whilst the resulting economic burden on low-income households is more ponderous (e.g. Feldman 1994). These findings relate to the USA in most cases. There is however uncertainty with regard to the retirement age in relation to the financial circumstances for the situation in Germany. Radl (2007: 47) refers to empirical surveys by Drobnič and Schneider (2000), as well as by Wübbeke (2005), in which it was shown that there is no linear relationship between the statistical risk 
of early retirement and the amount of income, but that an inverse u-shape one does exist. This means that the retirement risk first of all increases with the amount of income, but then falls once more. This pattern has also shown itself, inversely, but following the same logic in US studies that were related to employment in retirement. The interpretation of this $u$ shape leads to the conclusion that on the one hand there are people who would like to voluntarily continue to work in retirement and on the other people who have to work for financial reasons (Pleau 2010: 271).

In Germany especially the investigations on various retirement paths carried out by Radl (2007) and by Himmelreicher et al. (2009) should be mentioned which deal with retirement conduct in relation to the level of education. According to the literature which they inspected the latter group of authors found that (highly) qualified employees in Germany retire much later than those with fewer skills (Himmelreicher et al. 2009: 438). A major finding of their study was that persons with a low level of education in employment tend to leave working life between 60 and 63 , whilst those who have received more training tend to leave the labour market between the ages of 63 and 65, indicating better labour market prospects for those with a higher level of skills. One interesting aspect here was that comparing the retirement conduct of women from the old and the new Federal Länder showed a variety of patterns. The conduct of women in the old Länder was very similar to that of men; the peaks of retirement were recognisable at age levels of 60 (primarily skilled and low-skilled women) and 65 (highly-skilled women in the majority). The transition to retirement in Eastern Germany was mostly completed at the age of 63 . Highly-skilled women tended to retire at 65 (Himmelreicher et al. 2009). Radl (2007) made it clear using the retirement data for 2004 that the pension insurance status has proven to be a suitable indicator with regard to the attribution of various social groups:

“Especially employees with a higher level of education and a good income frequently even prefer to continue to work until the conventional age limit of 65 . With their tendency to retire late, they show themselves to be partly resistant to financial incentives to retire early. In view of the findings, one may presume that the loss of prestige in the case of retirement is higher for academics than for those with fewer skills." (Radl 2007: 59-60.)

The connection between socioeconomic status and the extension of life working time should be examined separately for women and men, given that "the effect of SES [socio-economic status] on a person's workforce participation depends on gender roles" (Komp et al. 2010: 47; authors' notes). Women for instance show a lower workforce participation, which is caused to a considerable degree by the problems occurring in reconciling work and family obligations. These problems also play a larger role among women than among men if they decide to stay in working life for longer (Clemens 2006; Komp et al 2010). Multivariate analyses of Plaeu (2010) regarding employment conduct in retirement also show that statistically-significant effects occur only for women in connection with specific sociodemographic characteristics (marital status, income and assets). 


\section{Theoretical considerations to explain willingness to continue in employment}

Various theoretical approaches are used to explain retirement and continuation in employment in retirement age. The term retirement relates here both to the transition from working life to retirement and to the individual's adjustment process in the retirement phase. This article studies the phase prior to retirement in order to identify the degree to which dependent employees have any willingness at all to remain in working life for longer, and what reasons speak for or against this, the focus remaining on the socioeconomic characteristics.

Retirement literature very frequently refers to the role theory, the life course perspective and the continuity theory (e.g. Wang 2007; Kim/Moen 2002 or restricted to the continuity theory and life course perspective in Bonsdorff et al. 2009, as well as Smith 2004 in relation to voluntary commitment in retirement). The objective is to briefly illustrate these theoretical approaches, but not to compare them, especially since there are major interfaces between these approaches. Rather, they are used as a supplement when forming the hypotheses leading the research.

\subsection{Role theory}

When it comes to the role theory, particular interest attaches to role gains and losses, as well as to the relative shifts in the roles within a bundle of roles. In order to obtain a better understanding of possibly continuing in employment when retired, it is relevant to learn how the individuals perceive their future role changes (losing the "productive worker role" and gaining the role of the "inactive retiree") in their remaining working life.

The individual is a holder of various roles, some of which compete with one another. The vocational roles are compared with a variety of roles outside working life, such as the role as a partner, as a member of the family or as a member of a specific community. With regard to approaching the end of working life, it is above all a matter of how persons in employment who are becoming older are able to perceive and evaluate the future shifts and rearrangements between their roles (for instance a strengthening of family-related roles and a weakening of the role as a working person). It is known from social science surveys that the tie to a specific role depends amongst other things on how central the role is to the identity of the individual. If the work-related role is a central element of identity, it is conceivable that transition to retirement is regarded as a critical event for the individual. This would express itself in that the loss of the role causes fear and depression and less well-being is anticipated in retirement. This may apply primarily to those individuals who have invested a particularly large amount of time and energy in their professional careers. The loss of the role as a manager (or as an employee with highly-skilled activities) may entail considerable difficulties in this context when it comes to adjusting, and this may result in a loss of perceived quality of life. Conversely, one may presume that persons who are highly engaged in other non-professional roles opt to leave working life earlier, as do those individuals in employment who find their jobs un- 
happy or unpleasant and are glad to be able to shed their work-related role. The loss of the role should hence be less grievous for persons who are in employment in the medium and/or lower levels of the company hierarchy than for persons in employment at the higher levels (Ashforth 2001; Barnes-Farrell 2003: 162-163; Kim/Moen 2002: 212-213; Carter/Cook 1995; Wang 2007: 456; Smith 2004: 58). We therefore presume that there is a positive connection between willingness to continue in employment in retirement age and the professional position within the organisation.

\subsection{Life course perspective}

This approach observes events and sequences which are dependent on age and life phase over a lifetime and their consequences for the individual and his/her social environment (Elder 1995). The transition to retirement marks a major transformation in the triple-division of the cultural and institutional view of a "normal" predefined life-course regime - preparatory, active and retirement phases -, albeit because of the increasing pluralisation of careers the calendar age can only be used as a rough indicator to draw a line between these phases (Kohli 1985; Wang 2007; Mayer 2001: 453).

On the basis of various interdependent relationships between the life domains in particular between the domains of work and of the family - the time of retirement is influenced by events from the earlier work and family life, as well as from the earlier training. Hank (2004), for instance, compares the retirement conduct of mothers with childless women in Western Germany. With data from the Socio-Economic Panel, he finds that retirement tended to be delayed more often by mothers than by childless women. This applies particularly if the first child was born relatively late. Furthermore, it is known from life course studies that the professional careers of women in comparison to men are more frequently characterised by family-related interruptions in work and poorer reintegration opportunities on the labour market. Mothers have fewer entitlements on the public old-age pension system as a result of these interruptions (e.g. Allmendinger 1994; Hank 2004). This circumstance might induce a catch-up process, i.e. the gaps from the earlier career biography are filled by taking up employment, whilst men tend to prepare for their retirement. It can hence be presumed that because of the gender-typical career biographies prevalent in (Western) Germany, differences exist between women and men with regard to willingness to continue in employment.

If one distinguishes in the life course perspective between socioeconomic characteristics, it can be found that (especially) in Western Germany in the course of the expansion in education the tendency to generally extend the education phase can be observed (Schmidt/Schmitt 2005: 309). The number of university graduates almost doubled between 1970 and 1990 (Dostal 2005: 481). After a comparatively longer training phase, individuals with academic titles have entered work later than those with a relatively low level of qualification. In section 2.3 empirical studies on retirement differentiates by education have also shown that a higher level of education has a delaying effect on retirement. One may hence presume for our research question that persons with a higher occupational status within the organisation 
(which as a rule is closely connected to the level of education) will leave working life later, and hence tend to be more willing to continue in employment in pensionable age.

\subsection{Continuity theory}

This approach suggests that people essentially remain the same over their lives in psychological terms: They retain by and large the same preferences, the same conduct patterns or the same social environments (Atchley 1989). These patterns constitute a major element of personal identity and of a feeling of self-esteem. This means that individuals prefer to retain these patterns despite pronounced changes in their personal environments (be it over their lifetimes, in the ageing process or in social change). Retaining the stability of certain patterns from the medium to the higher age steps forms an important adjustment strategy for the individual in the sense of successful ageing (Backes/Clemens 2003). ${ }^{4}$

If an individual is very active in middle age, it is highly likely that this level of activity will be retained, on condition that the corresponding state of health makes this possible. The continuation of earlier activities in retirement which were already carried out during the working phase would hence be a possibility. This can take the shape of a paid activity in the old job, but taking on other jobs would also be quite conceivable. Furthermore, the option can also be used to work on an honorary basis if this can be interpreted as "continuing" the former activity. The hypothesis of continuity is favoured for instance by the results of Wang (2007: 465). The author was able to find empirically that the lion's share of retirees (between 69 and $75 \%$ ) carry out the same activities as prior to their retirement.

The patterns which have been ascertained can be sub-divided into internal and external structures. The preservation of internal structures/patterns relates primarily to the cognitive skills, whilst the preservation of external contact relates to the contextual conditions. According to Atchley, there is internal pressure towards continuity since a fundamental need for stability was said to be firmly anchored in the individual. Pressure on the external structures arises because of changes in contextual conditions and the concomitant expectations as to the role played by the individual (cf. Atchley 1989: 183; Backes/Clemens 2003: 133). This article focuses on the external structures by taking a closer look at the indicators to describe socioeconomic status.

As far as socioeconomic characteristics are concerned, one may presume that a higher professional status of the individual is linked to more attractive behaviour and orientation patterns (greater individual scope and greater influence on the overall company result, as well as management of staff or responsibility for more mate-

4 Successful ageing is generally associated with a high level of satisfaction with life, with good social integration and with a good state of health. The term "successful ageing" is taken up differently in social sciences despite many efforts to establish a uniform definition (for a critical discussion cf. Hank 2011: 230). 
rial and financial resources). As a consequence, it can be presumed that particularly older employees in the higher organisational levels feel greater pressure towards continuity, and are hence more likely to be willing to continue working in retirement (analogously to actual employment in retirement - bridge employment - cf. Gobeski/Beehr 2009: 403; Feldman 1994: 296-297).

\subsection{Hypotheses}

Building on the theoretical information and the empirical findings, a positive connection can be presumed to exist between professional status in the organisation/ enterprise and the intention to be employed in retirement age. The hypothesis to be examined here is as follows:

1. Willingness to continue in employment in retirement age increases with a higher position in the company hierarchy.

As to household income, by contrast, a negative connection is indicated. In line with the empirical findings which have been portrayed (section 2.3), the following hypothesis can be derived:

2. Willingness to continue in employment in retirement age falls as the disposable household income rises.

The analyses are carried out separately for men and women. It is to be examined here whether the links actually prove to be gender-specific - as is shown in other empirical investigations. Two additional hypotheses can be formulated for this postulated interaction effect with gender:

3. The position within the company hierarchy plays a more important role for men's willingness to continue in employment because of their more pronounced preference towards autonomy (cf. section 2.2).

4. By contrast, income plays a more important role among women for willingness to continue in employment - as a result of the economic disadvantages caused by interrupted career biographies or by the comparably worse income situation over the life course (cf. sections 2.2 and 2.3).

\section{$4 \quad$ Empirical investigation}

\subsection{Data basis and method}

The data basis is formed by the study entitled "Continuing in employment in pensionable age", which was carried out by infratest in 2008 on behalf of the Federal Institute for Population Research. This survey aimed to investigate the willingness of older employees to engage (continue) in employment in retirement age and the concomitant conditions. For this purpose, a representative survey of dependent employees (this relates to blue-collar workers, white-collar workers and civil servants, persons in minor employment or employees in job creation or structural ad- 
justment schemes). All in all, 1,500 men and women aged from 55 to under 65 were surveyed. Self-employed persons or persons who were not in employment at the time of the survey (such as unemployed persons who were already in retirement or who were in the non-working phase of the old-age part-time working scheme) were not surveyed. The questionnaire was drawn up by the Federal Institute for Population Research in cooperation with the SRH University of Applied Sciences Berlin (former OTA University of Applied Sciences). The analyses below were carried out using the SPSS statistics program (Windows SPSS Version 13.0).

\subsection{Constructs and operationalisation}

\subsubsection{Willingness to continue in employment in retirement age}

The study entitled "Continuing in employment in pensionable age" covers the intention to continue in employment, but not the respective actual conduct. The intention of a person need not necessarily concur with their conduct, but, as described in section 2, should be taken into account as a major starting point for retirement conduct. If the reasons for specific conduct are collected retrospectively, distortions in memory may occur. By contrast, prospective recording can help to investigate which individuals express any willingness at all and under what conditions. Hence, important information is obtained as to which values exist relating to continuing in employment, but also which obstacles stand in the way. The study is hence used as a preliminary survey in which initial information on this so far little-researched topic is to be obtained. Subsequent investigations are to examine whether intention and conduct concur and to draw corresponding conclusions from any deviations.

The willingness of older workers to remain in working life for longer was measured by the following question: "Please let us ask a few more questions on the wishes and possibilities to continue in employment in retirement age. Do you wish to remain in employment after your retirement, for instance in minor employment". The possible answers "Yes" and "Probably" and "Probably not" and "No" were summed up to form a dichotomous variable, the characteristics ' 1 ' standing for persons who wish to continue in employment after retirement and ' 0 ' for those who do not wish to do so.

\subsubsection{Socioeconomic characteristics}

Two indicators of socioeconomic status are used to explain the differences with regard to willingness to extend working lifetimes: Professional status in the sense of a position in the company hierarchy and monthly household net equivalence income. $^{5}$

5 A third central indicator of socioeconomic status, namely the highest professional training qualification, was deliberately done without since there is a highly-pronounced correlation between the indicators, in particular between professional training qualification and the professional status. To examine the robustness of the results, all the analyses were carried out with the professional training qualification. This however only marginally changes the results. 
The professional status of the person was defined as a position within the professional hierarchy, deriving from the ISCO Classification of Occupations. ${ }^{6} \mathrm{~A}$ dichotomous variable was formed here. Characteristic 1 constitutes the higher status level of the professional hierarchy: master craftsperson, salaried employee with a highly-skilled activity or with managerial tasks and civil servants in the administrative service. By contrast, the characteristic 0 includes the so-called medium (specialist workers, salaried workers with skilled activities and the higher intermediate service) and the lower status level (unskilled and self-taught workers, salaried employees with simple activities and civil servants in the ordinary or intermediate service).

The monthly net household income of elderly employees was weighted using an equivalence scale according to household size (the square root of the number of household members was used as an equivalent weight since the dataset does not contain any information regarding the age of the household members; cf. on this Motel-Klingebie/ 2006) and summarised in three categories: up to Euro 1,500, Euro 1,500 to less than 2,000 and Euro 2,000 or more.

\subsubsection{Job-related characteristics}

In addition to status-related characteristics of older employees, empirical studies have shown that willingness to remain in employment beyond retirement age is influenced by a number of job-related characteristics (cf. section 2.2). This article takes account of a total of five job-related characteristics: the size of the enterprise, length with the individual enterprise, the average weekly working hours, the working conditions and past unemployment.

According to the definition of the European Union microenterprises, small, medium-sized, and large enterprises are differentiated according to the following three criteria: number of employees, amount of turnover and balance sheet total in a period. Since the present dataset only contains information on the number of employees in the enterprise or institution in which the person was employed at the time of the survey, it was only possible to classify the size of the enterprise using this information. For this reason, the delimitation remains uncertain to some degree. A total of four categories were formed: micro enterprises (fewer than 10 employees), small enterprises (10 to under 50 employees), medium-sized enterprises (50 to under 250 employees) and large enterprises (250 or more employees).

Affiliation with an enterprise in years was coded as a dichotomous variable. Characteristic 1 stands for a duration of affiliation with the enterprise of fewer than ten years and characteristic 0 for a duration of ten years and more. The selection of this threshold tallies with the observation that persons in employment in Germany on average remain in their enterprise for roughly ten years (Rhein 2010).

6 It was not possible with this dataset to group the professions according to the ISCO Classification or to attribute the respondents according to the ISCED Classification since information was only available on the highest educational qualification, but not on the highest general school qualification. 
When it comes to the average weekly working hours, a distinction is made between the following three categories: less than 15 hours, 15 to under 35 hours, and 35 or more hours per week. The numbers of hours here relate to the actual hours worked (including overtime) by older workers in a normal week at the time of the survey. The three selected classes hence roughly correspond to the employment relationships "minor employment", "part-time employment" and "full-time employment".

Unemployment is inserted into the study as a dichotomous variable (person had already been unemployed at the time of the survey, person was not unemployed).

The working conditions of older employees were included in the analyses as the last job-related characteristic. These were included with a total of eleven items, each of which relates to the description of a concrete working condition (environmental influences such as noise or temperature, as well as psychological strains). Respondents are asked to state here to what degree these conditions relate to their work. It was possible for the respondents to grade their responses with the aid of a fixed set of response items (from "absolutely correct to "not at all correct"). An additive index was formed on the basis of an explorative factor analysis which ultimately comprises the following seven items: "My work requires a high working pace.", "My work is strenuous.", "My work is physically difficult.", "My work is hazardous to my health.", "I am exhausted after work.", "I feel under constant pressure at work." and "I find it difficult to switch off after work.". The index formed hence serves as an indicator of the extent of strenuous, physical and mentally-taxing working conditions, and covers a value range of 0 to 28 (items were recoded for this to $0-4$ ), higher values standing for worse working conditions. The median value of the scale is 14.6.

\subsubsection{Demographic characteristics}

The selection of the demographic control variables relates to the empirical findings presented at section 2.3 concerning the determinants of employment in retirement. In addition to gender ( 1 "male" and 0 "female") and age (metric), the marital status ( 1 "married" and 0 "unmarried"), as well as the subjective state of health ( 1 "very good" and "rather good" and 0 "satisfactory", "rather poor" and "very poor") of older employees was taken into account in the analyses.

\section{$5 \quad$ Results}

\subsection{Descriptive analysis}

In the sample surveyed, $47.2 \%$ of respondents aged from 55 to 64 , that is almost half, consider the possibility of continuing in employment beyond their retirement age. The respondents are willing to continue to work for an average of 4.1 years after retirement, working hours averaging 15.1 per week. The majority of them prefer individual, flexible design possibilities: If the elderly can imagine continuing in employment, they would mostly like to decide for themselves when and how often 
Tab. 1: Conditions for continuing in employment

\begin{tabular}{lrr}
\hline Older employees willing to continue in employment & in \% \\
\hline Willingness to continue in employment & 47.2 \\
Desired frequency of continued & Daily. & 5.5 \\
employment in retirement & On 3-4 days per week. & 18.0 \\
& On 1-2 days per week. & 24.2 \\
& On several days per month. & 3.5 \\
& On standby when I am needed. & 12.1 \\
& I would like to be able to decide freely. & 36.7 \\
Desired workplace to continue & In my previous job. & 36.0 \\
in employment when retired & At home. & 9.4 \\
& Both. & 21.6 \\
\hline
\end{tabular}

$\mathrm{N}=699(1.480)$

Source: Weiterbeschäftigungssurvey 2008, BiB. Unweighted data. Own calculations.

they do so, and as a rule they no longer want to work every day. Some respondents can also imagine working on a standby basis when they are needed. A large share of the individuals would furthermore like a change with regard to their workplace (e.g. an activity which can also be carried out from home or a change of job).

According to this initial view of the data structure, the question now arises as to whether there are differences between those who can imagine continuing in employment and those who cannot imagine doing so. To this end, Table 2 presents the spread of 55- to 64-year-olds as to willingness to continue in employment.

Within the sample surveyed, it is possible to recognise statistically-significant differences among the demographic characteristics with regard to age and marital status. It is therefore shown that those individuals who are willing to continue in employment are on average older than those who are not. Married people are much less willing in comparison to the unmarried. The differences by gender and subjective state of health, by contrast, are slight and are not statistically significant.

When it comes to the job-related characteristics, by contrast, pronounced and statistically-significant differences can be recognised between the elderly, who (tend to) show a willingness to continue in employment, and those who refuse to remain in employment in retirement. Thus, agreement tends to be higher among respondents working for smaller enterprises. Respondents who have been employed by their current employer for fewer than ten years are more likely to be willing to remain in employment after retirement than respondents who have been employed by their current employers for more than ten years. As to the respondents' average weekly working hours, a negative connection is also shown: With falling weekly working hours, the share of the elderly who wish to continue in employment in- 
Tab. 2: The spread of plans to continue in employment in retirement age (percent and median values)

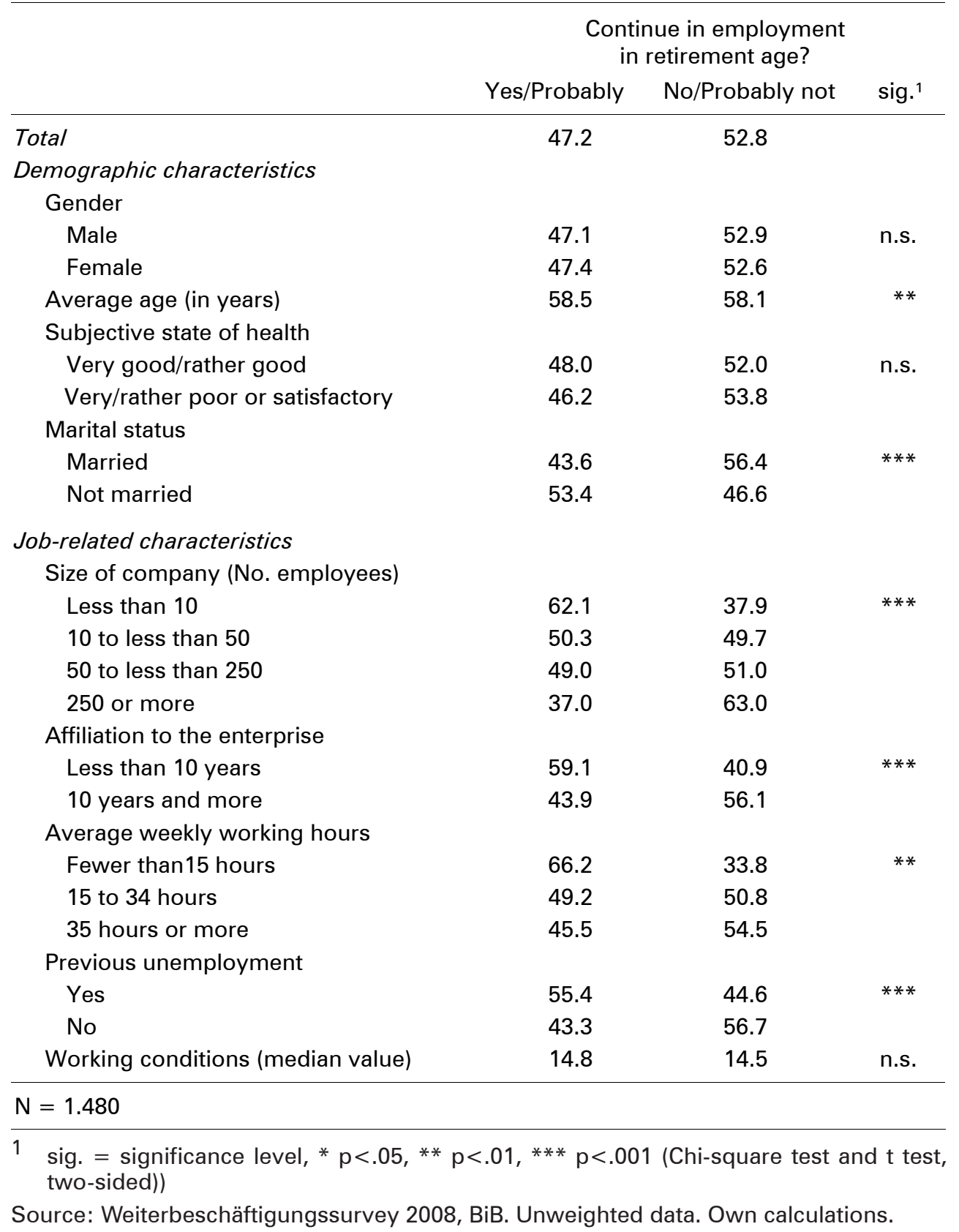


creases. As to unemployment, it can be recognised that willingness tends to be higher among those who had experienced past unemployment at the time of the questionnaire than among those who had so far been spared unemployment. Finally, as the last job-related characteristic, the working conditions of the employment exercised by the older employees were observed. This index can be interpreted as an indicator of the degree of physically and mentally strenuous working conditions, in which higher values stand for less favourable working conditions. The median values for both categories of willingness to continue in employment were calculated and compared. Surprisingly, only slight differences which are statistically insignificant emerge here between those who are willing to continue in employment when retired and those who are not. One might very much rather expect individuals with poor, strenuous working conditions to be less willing, and by contrast those with very good working conditions to be more willing to continue in employment beyond retirement.

In the next step the connection between plans to continue in employment and central socioeconomic characteristics of the respondent are analysed. Are respondents with a higher socioeconomic status more willing to continue in employment beyond retirement? What is the situation when it comes to the willingness to continue in employment of those on a higher income in comparison with those who earn less? The spread of the plans to continue in employment is portrayed in Figures 2 and 3 according to professional status and income.

When it comes to professional status, a positive correlation is indicated corresponding to hypothesis 1 - willingness to continue in employment increases with

Fig. 2: The spread of plans to continue in employment in retirement age by professional status (answer yes/probably in percent)

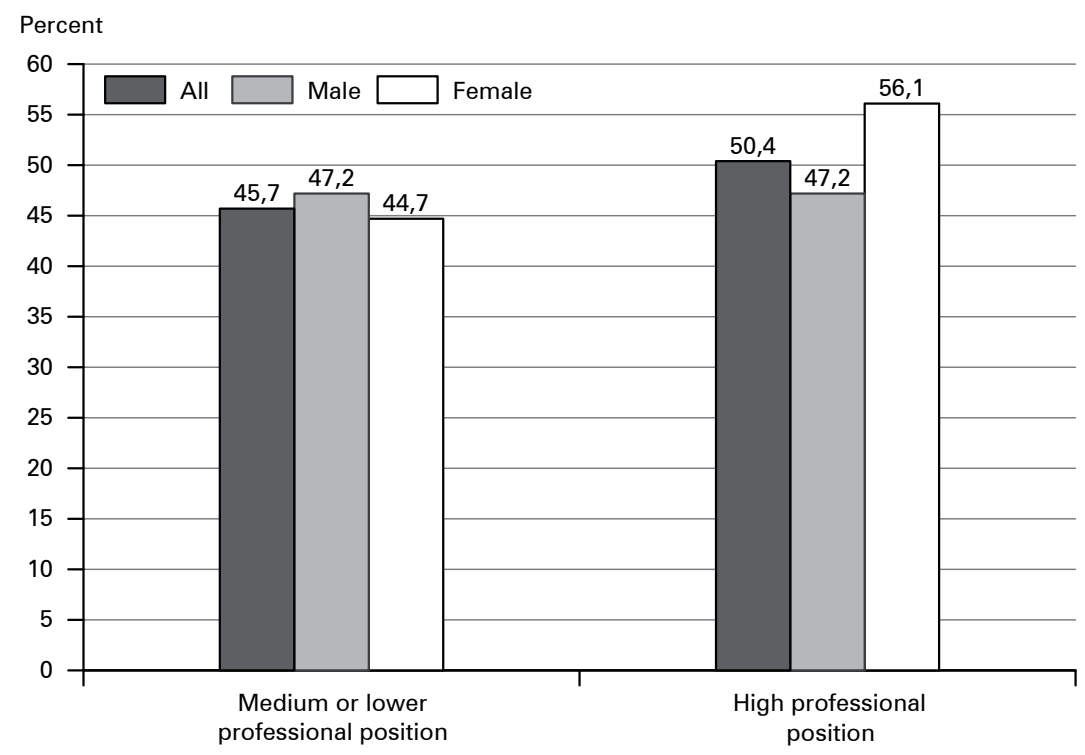

Source: Weiterbeschäftigungssurvey 2008, BiB. Unweighted data. Own calculations. 
Fig. 3: The spread of plans to continue in employment in retirement age by net household income (answer yes/probably in percent)

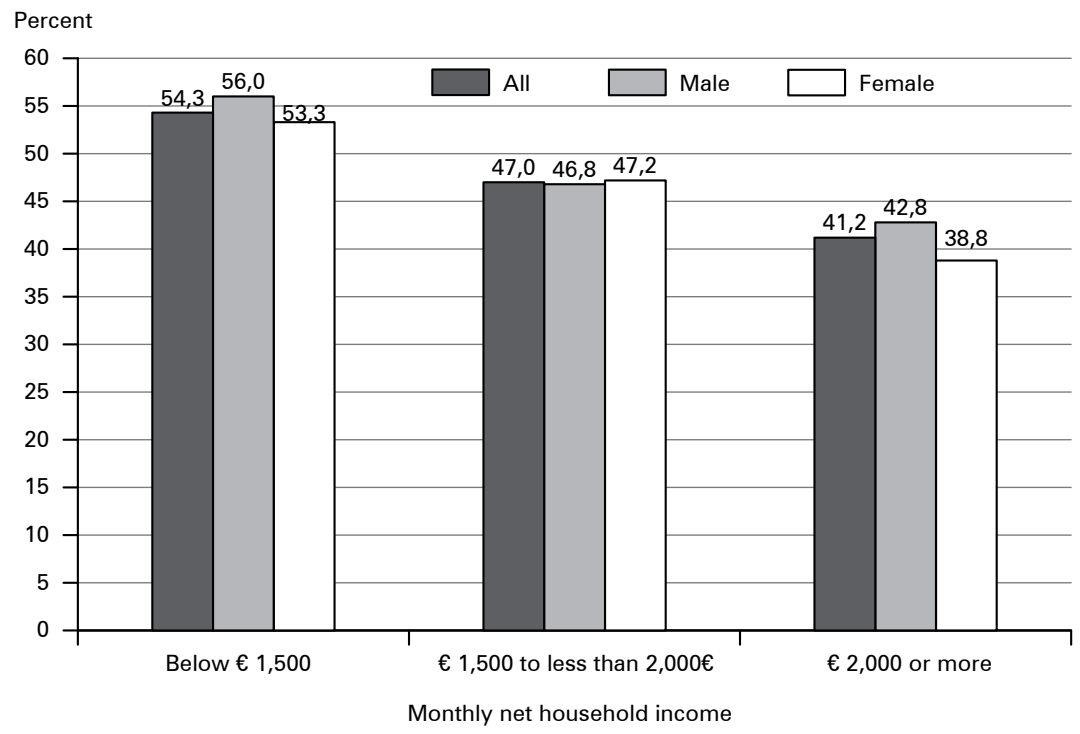

Source: Weiterbeschäftigungssurvey 2008, BiB. Unweighted data. Own calculations.

a higher professional position - but this is only significant at the $10 \%$ level. Pronounced statistically-significant differences are shown, by contrast, when it comes to income. In the sense of hypothesis 2 , in this case willingness to continue in employment falls in line with socioeconomic status: Willingness to continue in employment in pensionable age is greater the lower the monthly net household income of the person is. This finding indicates in particular an economic incentive to continue in employment in retirement age.

Is this correlation between the indicators of socioeconomic status the same among women and men, or do the data reveal signs of an interaction effect?

Whilst no major differences in willingness to continue in employment between women and men are shown with regard to household income the picture is different when it comes to professional status. If men and women are regarded separately, there are no differences among men between those who had a high professional status at the time of the survey and those with a medium or lower professional status. The share of those who could imagine continuing in employment beyond retirement age is equally large in both groups. Among women, by contrast, pronounced, statistically-significant differences are shown. A much larger share of women with a high professional status state that they wish to remain in employment after the transition to retirement, compared with women who had a medium or lower professional status. The finding that it is only after considering gender that the socioeconomic differences found prove to be statistically significant corresponds with the analyses of Pleau (2010) on the employment conduct of retirees. 


\subsection{Multivariate analysis}

This section examines whether the correlations that have been ascertained also remain once various interfering variables have been statistically controlled for. With binary logistic regression models we attempt to find an answer to the question of which variables produce these differences and how they influence the extent and direction of the correlation. Three binary logistic regression models were calculated (general information on the methods can be found for instance in Tabachnick/Fidell 2007: 437-505), in which the model variables were inserted stepwise (Tab. 3). The first model only contains the central explanatory variables: the professional status and the income of the respondent. The second model was expanded to include the job-related characteristics of the person, of which it is presumed that they also exert an influence on continuing in employment. The last model additionally contains the individual control variables.

A statistically-significant correlation is shown between the socioeconomic characteristics and willingness to continue in employment which is maintained over all three models. When controlling for the other covariates, the likelihood of being willing to continue in employment is greater among those who had a high professional status at the time of the questionnaire than among those with a medium or low professional status. By contrast, the probability of continuing in employment is lower the higher the monthly net household income. The results hence confirm the descriptive findings.

The size of the enterprise as a central job-related characteristic of the respondent also makes a significant contribution towards explaining the differences in willingness to continue in employment. The smaller the enterprise (in terms of numbers of employees) in which the persons are employed at the time of the interview, the more likely they are to be willing to continue in employment after retirement age. And a positive correlation is also shown in case of unemployment: Willingness to continue in employment is significantly higher among those who stated that they had already been unemployed in their previous working life than among those who had not previously been unemployed. Respondents who have been employed by the same employer for ten years and more show a lesser chance to be willing to continue in employment in comparison to those respondents who have been employed for a shorter time. Neither job-related characteristic, that is average weekly working hours and working conditions, by contrast, makes a contribution of its own towards explaining the differences.

In addition, the age or subjective state of health of the person do not make any contribution towards an explanation. Having said that, significant correlations exist between willingness to continue in employment and gender. For instance, in comparison to women, men show a statistically-significant greater likelihood if one keeps the other covariates constant. A significant negative correlation is shown as to marital status: The likelihood to be willing to continue in employment is higher among married people than among those who are not married.

As was already the case in the descriptive analysis, in the last step the correlation is separated once more by gender (Tab. 4). The findings already presented 
Tab. 3: Binary logistic regression models for plans to continue in employment in retirement age

\begin{tabular}{|c|c|c|c|c|c|c|}
\hline & \multicolumn{2}{|c|}{ Model 1} & \multicolumn{2}{|c|}{ Model 2} & \multicolumn{2}{|c|}{ Model 3} \\
\hline & Beta & $\mathrm{p}$ & Beta & $\mathrm{p}$ & Beta & $\mathrm{p}$ \\
\hline \multicolumn{7}{|l|}{ Socioeconomic characteristics } \\
\hline \multicolumn{7}{|l|}{ Professional Status } \\
\hline $\begin{array}{l}\text { ( } 0=\text { medium or low professional } \\
\text { position, } 1=\text { high professional position) }\end{array}$ & .419 & $* * *$ & .524 & $* * *$ & .490 & $* * *$ \\
\hline \multicolumn{7}{|l|}{ Monthly net household income } \\
\hline below $€ 1,500$ & .715 & $* * *$ & .520 & $* * *$ & .465 & $* *$ \\
\hline$€ 1,500$ to less than 2,000 & .346 & $* *$ & .276 & * & .282 & * \\
\hline$€ 2,000$ and more ${ }^{a}$ & - & - & - & - & - & - \\
\hline \multicolumn{7}{|l|}{ Job-related characteristics } \\
\hline \multicolumn{7}{|l|}{ Size of enterprise } \\
\hline under 10 employees & & & .894 & $* * *$ & .972 & $* * *$ \\
\hline 10 to under 50 employees & & & .354 & * & .384 & $* *$ \\
\hline 50 to under 250 employees & & & .351 & * & .378 & $* *$ \\
\hline 250 employees and more ${ }^{a}$ & & & - & - & - & - \\
\hline \multicolumn{7}{|l|}{ Time in enterprise } \\
\hline$(0=10$ years and longer, $1=$ under 10 years $)$ & & & .330 & * & .300 & * \\
\hline \multicolumn{7}{|l|}{ Average weekly working hours } \\
\hline 0 to 14 hours per week & & & .398 & n.s. & .510 & n.s. \\
\hline 15 to 34 hours per week & & & -.028 & n.s. & .134 & n.s. \\
\hline 35 hours per week and more ${ }^{-a}$ & & & - & - & - & - \\
\hline \multicolumn{7}{|l|}{ Unemployment } \\
\hline $\begin{array}{l}\text { ( } 0=\text { never been unemployed, } 1=\text { been } \\
\text { unemployed })\end{array}$ & & & .285 & * & .305 & * \\
\hline Scale working conditions & & & .011 & n.s. & .016 & n.s. \\
\hline \multicolumn{7}{|l|}{ Demographic characteristics } \\
\hline \multicolumn{7}{|l|}{ Gender } \\
\hline$(0=$ female, $1=$ male $)$ & & & & & .295 & * \\
\hline Age & & & & & .295 & n.s. \\
\hline \multicolumn{7}{|l|}{ Subjective state of health } \\
\hline $\begin{array}{l}\text { ( } 0=\text { satisfactory or worse, } 1=\text { very good or } \\
\text { good })\end{array}$ & & & & & .106 & n.s. \\
\hline \multicolumn{7}{|l|}{ Marital Status } \\
\hline$(0=$ not married, $1=$ married $)$ & & & & & -.402 & $* * *$ \\
\hline Constant & -.591 & $* * *$ & -1.188 & $* * *$ & -1.220 & $* * *$ \\
\hline Pseudo- $\mathrm{R}^{2}$ & .0 & & .08 & & .09 & \\
\hline
\end{tabular}

Source: Weiterbeschäftigungssurvey 2008, BiB. Unweighted data. Own calculations. 
Tab. 4: Group-differentiated analysis: Binary logistic regression models for plans to continue in employment in retirement age, separated for gender

\begin{tabular}{|c|c|c|c|c|c|c|}
\hline & \multicolumn{2}{|c|}{ Total } & \multicolumn{2}{|c|}{ Men } & \multicolumn{2}{|c|}{ Women } \\
\hline & Beta & $\mathrm{p}$ & Beta & $\mathrm{p}$ & Beta & $\mathrm{p}$ \\
\hline $\begin{array}{l}\text { Socioeconomic characteristics } \\
\text { Professional status } \\
\quad(0=\text { medium or low professional position, } \\
1=\text { high professional position) }\end{array}$ & .490 & $* * *$ & .235 & n.s. & .813 & $* * *$ \\
\hline Monthly net household income & & & & & & \\
\hline below $€ 1,500$ & .465 & $* *$ & .335 & n.s. & .662 & ** \\
\hline$€ 1,500$ to to less than 2,000 & .282 & * & .057 & n.s. & .487 & * \\
\hline$€ 2,000$ and more ${ }^{a}$ & - & - & - & - & - & - \\
\hline Constant & -1.220 & $* * *$ & -.759 & $*$ & -1.500 & $* * *$ \\
\hline Pseudo- $\mathrm{R}^{2}$ & .09 & & .11 & & .10 & \\
\hline
\end{tabular}

a Reference category. Regression coefficients and p-values. Significance levels: ${ }^{*} p<.05$, ${ }^{* *} \mathrm{p}<.01,{ }^{* * *} \mathrm{p}<.001$

Source: Weiterbeschäftigungssurvey 2008, BiB. Unweighted data. Own calculations. Controlled for size of enterprise, affiliation to enterprise, weekly working hours, unemployment, working conditions, gender, age, subjective state of health and partnership status.

are confirmed here. If one takes a look solely at men, the correlations between the two indicators of socioeconomic status and willingness to continue in employment become insignificant, whilst they are much more marked among women and also highly significant. These findings indicate that it is especially women in high professional positions and women with a low household income who show a greater chance of being willing to continue in employment.

Let us briefly summarise the results against the background of the hypotheses put forward in section 3.4. Both hypotheses (willingness to continue in employment in pensionable age increases with a higher position within an organisation, and falls with a higher household income) are supported by the findings. On principle, the direction of the presumptions can be recognised in the data; the connections ascertained are however only statistically significant among women according to the gender-differentiated analysis. For instance, it is possible to confirm the fourth hypothesis, but not the third one. This means that both household income and professional status appear to play a more important role for women. 


\section{Discussion and methodical restrictions}

This article aimed to explore the intentions of older employees to remain in working life for longer and their reasons for that intention. This question is particularly relevant since the future demographic and pension law framework requires people to remain in the working world for longer. Legal and economic implications of the increase in the statutory retirement age are only one possibility on offer to benefit from the economic potential of baby-boomers who are getting older. However, are people not in fact willing to work beyond 65 voluntarily, and if they are, under what conditions? Using the dataset "continuation in employment in pensionable age", it is first of all possible to examine intentions related to a possible extension of working lives. Hence, a first step was taken towards explaining the retirement process. This says nothing final about the decision itself as to whether or not to leave the labour market

The descriptive investigation of the dataset already provides central findings which make a major contribution regarding the question, which has very recently been at the heart of political and public awareness, as to the workforce potential of older people. For instance, some frameworks can be named within which continuing in employment when retired appears more attractive from the point of view of older employees: Greater autonomy and more flexibility through reduced, flexible working hours and days or through a free choice of workplace, for instance through working at home. Also a change towards physically less strenuous and demanding work should be taken into account. In the future it will therefore be necessary for policy-makers and industry to facilitate a flexible progression into retirement and to establish a flexible framework.

The multivariate analyses indicate that professional status as an indicator of socioeconomic status also exerts a positive influence on willingness to remain in employment after the transition into retirement. Having said that, this connection appears to be gender-specific. Hence, in particular for women professional status can be considered to be a motivating factor to continue in employment.

It is however not possible to confirm this positive connection between socioeconomic status and willingness to continue in employment for the second indicator. Rather, income emerges as a major negative influencing factor. Here too, however, the connection appears to differ on a gender-specific basis.

Although all three models (and the explanatory variables observed) make significant contributions towards explaining the variance in the dependent variable, it should however be pointed out that this contribution towards an explanation, measured against the standards of the quality of the model (pseudo $R^{2}$ between 0.03 and 0.09 ), is relatively small. This leads to the conclusion that further characteristics which have not yet been taken into account explain the wish to continue in employment in retirement age, are still to be examined and should be taken into account in further investigations.

With regard to the survey, some weaknesses should be mentioned which may impair the explanatory power of the results. Firstly, typical selection effects cannot be ruled out for the labour markets as to the characteristics of health or educa- 
tional qualification. Since individuals who are not in employment (any more) for e.g. health reasons were not surveyed, an important group is not considered. For this reason, the relatively positive evaluations of working conditions and the relatively pronounced positive evaluation of the state of health (also among employees whose work is physically difficult) should not come as too much of a surprise. Also with regard to education, one has to anticipate a positive bias. Individuals with low educational qualifications have much poorer prospects on the labour markets than those with high levels of qualification. These discrepancies even increase with age (e.g. Fuchs 2006). In addition, the self-employed, who constitute a separate group with regard to the transition to retirement, are not included in this survey. The results and the implications of our survey therefore relate only to a selective section of the ageing working population, namely older dependent employees, who tend to be more healthy and more highly educated. Future research should hence also take account of the intentions to continue in employment in retirement age of older persons who are not in employment and who are confronted with the known difficulties in Germany of reintegration into the labour market (Heywood et al. 2010), or who are self-employed.

With regard to the political implications, the survey showed that the previous presumption of normality regarding the transition to retirement (cf. also Radl 2007: $46-47)$, that is time-related retirement at 65 , is becoming further diluted and that the debates on leaving working life should be orientated more closely towards socioeconomic aspects. The observations listed in the Fifth National Social Report on the Situation of the Elderly in Germany (Fünfter Bericht zur Lage der älteren Generation in der Bundesrepublik Deutschland) that different cultures have formed with regard to the desire to retire (cf. section 2.1) make it clear that the possibilities to leave working life should both permit early retirement for the health-impaired working population, and encourage the older working population who indicate a willingness to continue in employment in retirement age to remain in work beyond 65 . Furthermore, it should be taken into account when drafting policy on the aged which persons would like to work on and who have to. This also matches the results of Flynn (2010), who concluded in his investigation that there was no "one-size-fitsall" approach for political decision-makers. It is hence important to take account of the entire range of older employees in terms of their individual characteristics and preferences in relation to workplace design in the event of an extension of working lifetime. If, therefore, one reflects on the opening up of potentials offered by the elderly in the working world a socio-economically differentiated, gender-specific view would be recommended.

\section{Acknowledgements}

The authors would like to thank two anonymous reviewers for their valuable comments. 


\section{References}

Adams, Gary A.; Beehr, Terry A.; Prescher, Julie; Lepisto, Lawrence 2002: Applying work-role attachment theory to retirement decisions. In: International Journal of Aging and Human Development 54,2: 125-137.

Allmendinger, Jutta 1994: Lebensverlauf und Sozialpolitik. Die Ungleichheit von Mann und Frau und ihr öffentlicher Ertrag. Frankfurt am Main/New York: Campus Verlag.

Ashforth, Blake E. 2001: Role Transitions in Organizational Life. An Identity-based Perspective. Mahwah, NJ: Erlbaum.

Atchley, Robert C. 1989: A Continuity Theory of Normal Aging. In: The Gerontologist 29,2: 183-190 [doi:10.1093/geront/29.2.183].

Atchley, Robert C.; Robinson, Judith L. 1982: Attitudes toward Retirement and Distance from the Event. In: Research on Aging 4,3: 299-313 [doi:10.1177/0164027582004003 002].

Bäcker, Gerhard; Brussig, Martin; Jansen, Andreas; Knuth, Matthias; Nordhause-Janz, Jürgen 2009: Ältere Arbeitnehmer. Erwerbstätigkeit und soziale Sicherheit im Alter. Wiesbaden: VS Verlag für Sozialwissenschaften.

Backes, Gertrud M.; Clemens, Wolfgang 2003: Lebensphase Alter. Eine Einführung in die sozialwissenschaftliche Alternsforschung. Grundlagentexte Soziologie. $2^{\text {nd }}$ Edition. Weinheim/München: Juventa.

Barnes-Farrell, Janet L. 2003: Beyond Health and Wealth: Attitudinal and Other Influences on Retirement Decision-Making. In: Adams, Gary A.; Beehr, Terry A. (Eds.): Retirement. Reasons, processes, and results. New York: Springer: 159-187.

Beehr, Terry A. 1986: The process of retirement: A review and recommendations for future investigation. In: Personnel Psychology 39,1: 31-55 [doi:10.1111/j.1744-6570.1986. tb00573.x].

Beehr, Terry A.; Glazer, Sharon; Nielson, Norma L.; Farmer, Suzanne J. 2000: Work and Nonwork Predictors of Employees' Retirement Ages. In: Journal of Vocational Behavior 57,2: 206-225 [doi:10.1006/jvbe.1999.1736].

Blau, David M.; Riphahn, Regina T. 1999: Labor force transitions of older married couples in Germany. In: Labour Economics 6,2: 229-252.

Blekesaune, Morten; Solem, Per E. 2005: Working Conditions and Early Retirement. In: Research on Aging 27,1: 3-30 [doi:10.1177/0164027504271438].

Bonsdorff, Monika E. von; Shultz, Kenneth S.; Leskinen, Esko; Tansky, Judith 2009: The Choice Between Retirement and Bridge Employment: A Continuity Theory and Life Course Perspective. In: The International Journal of Aging and Human Development 69,2: 79-100 [doi:10.2190/AG.69.2.a].

Börsch-Supan, Axel; Wilke, Christina 2009: Zur mittel- und langfristigen Entwicklung der Erwerbstätigkeit in Deutschland. In: Zeitschrift für ArbeitsmarktForschung 42,1: 29-48 [doi:10.1007/s12651-009-0006-x].

Brown, Michael T.; Fukunaga, Christie; Umemoto, Dawn; Wicker, Lori 1996: Annual Review, 1990-1996: Social Class, Work, and Retirement Behavior. In: Journal of Vocational Behavior 49,2: 159-189 [doi:10.1006/jvbe.1996.0039].

Brussig, Martin 2010a: Erwerbstätigkeit im Alter hängt vom Beruf ab. Ausdifferenzierung der Erwerbschancen vor allem nach dem 60. Lebensjahr, in einigen Berufen aber schon früher. Altersübergangs-Report 2010-05. Duisburg, Düsseldorf: Institut Arbeit und Qualifikation, Hans-Böckler-Stiftung [http://www.iaq.uni-due.de/auemreport/2010/2010-05/auem2010-05.pdf]. 
Brussig, Martin 2010b: Fast die Hälfte aller neuen Altersrenten mit Abschlägen - Quote weiterhin steigend. Probleme mit dem Anstieg der Altersgrenzen vor allem bei Arbeitslosen, aber auch bei Erwerbstätigen. Altersübergangs-Report 2010-01. Duisburg, Düsseldorf: Institut Arbeit und Qualifikation, Hans-Böckler-Stiftung [http://www.iaq. uni-due.de/auem-report/2010/2010-01/auem2010-01.pdf].

Brussig, Martin 2010c: Zunahme an Teilzeitbeschäftigung. Inzwischen steigt auch die Erwerbsbeteiligung im Rentenalter. Altersübergangs-Report 2010-03. Duisburg, Düsseldorf: Institut Arbeit und Qualifikation, Hans-Böckler-Stiftung [http://www.iaq.unidue.de/auem-report/2010/2010-03/auem2010-03.pdf].

Caro, Francis G. 2008: Produktives Altern und ehrenamtliches Engagement in den USA. Konzeptuelle Überlegungen, empirische Befunde und Implikationen für die Politik. In: Erlinghagen, Marcel; Hank, Karsten (Eds.): Produktives Altern und informelle Arbeit in modernen Gesellschaften. Theoretische Perspektiven und empirische Befunde. Alter(n) und Gesellschaft 16. Wiesbaden: VS Verlag für Sozialwissenschaften: 75-90.

Carter, Mary A.T.C.; Cook, Kelli 1995: Adaptation to Retirement: Role Changes and Psychological Resources. In: The Career Development Quarterly 44,1: 67-82.

Clemens, Wolfgang 2006: Ältere Arbeitnehmerinnen in Deutschland. In: Zeitschrift für Gerontologie und Geriatrie 39,1: 41-47 [doi:10.1007/s00391-0366-6].

Deutsche Rentenversicherung Bund 2009: Rentenversicherung in Zeitreihen. Issue 2009. DRV Schriften 22. Berlin

Deutscher Bundestag 2006: Fünfter Bericht zur Lage der älteren Generation in der Bundesrepublik Deutschland. Potenziale des Alters in Wirtschaft und Gesellschaft - Der Beitrag älterer Menschen zum Zusammenhalt der Generationen und Stellungnahme der Bundesregierung. Bundestagsdrucksache 16/2190.

Doeringer, Peter B. 1990: Economic security, labor market flexibility, and bridges to retirement. In: Doeringer, Peter $B$. (Eds.): Bridges to retirement. Older workers in a changing labor market. Ithaca, NY: ILR Press School of Industrial and Labor Relations Cornell University: 3-19.

Dostal, Werner 2005: Qualifikation und Arbeitsmarktdynamik. In: Soziologisches Forschungsinstitut (SOFI) et al. (Eds.): Berichterstattung zur sozioökonomischen Entwicklung in Deutschland. Arbeit und Lebensweisen. Erster Bericht. Wiesbaden: VS Verlag für Sozialwissenschaften: 481-504.

Drobnič, Sonja; Schneider, Thorsten 2000: Der Übergang erwerbstätiger Ehepartner in den Ruhestand aus der Lebenslaufsperspektive. In: Heinz, Walter R. (Eds.): Übergänge, Individualisierung, Flexibilisierung, und Institutionalisierung des Lebensverlaufs. Zeitschrift für Soziologie der Erziehung und Sozialisation 3. Beiheft: 205-220.

Ekerdt, David J. 2009: Population Retirement Patterns. In: Uhlenberg, Peter (Eds.): International Handbook of Population Aging. International Handbooks of Population. Dordrecht/Heidelberg: Springer: 471-491.

Ekerdt, David J.; Kosloski, Karl; Deviney, Stanley 2000: The Normative Anticipation of Retirement by Older Workers. In: Research on Aging 22,1: 3-22 [doi:10.1177/0164027500221001].

Elder, Glen H. 1995: The Life Course Paradigm: Social Change and Individual Development. In: Moen, Phyllis; Elder, Glen H.; Lüscher, Kurt (Eds.): Examining Lives in Context: Perspectives on the Ecology of Human Development. Washington, DC: American Psychological Association: 101-139. 
Engstler, Heribert 2006: Erwerbsbeteiligung in der zweiten Lebenshälfte und der Übergang in den Ruhestand. In: Tesch-Römer, Clemens; Engstler, Heribert; Wurm, Susanne (Eds.): Altwerden in Deutschland. Sozialer Wandel und individuelle Entwicklung in der zweiten Lebenshälfte. Wiesbaden: VS Verlag für Sozialwissenschaften: 85-154.

Feldman, Danie/ C. 1994: The Decision to Retire Early: A Review and Conceptualization. In: The Academy of Management Review 19,2: 285-311.

Flynn, Matthew 2010: Who would delay retirement? Typologies of older workers. In: Personnel Review 39,3: 308-324 [doi:10.1108/00483481011030511].

Franz, Wolfgang 2003: Arbeitsmarktökonomik. $5^{\text {th }}$ Edition. Berlin u.a.: Springer.

Fuchs, Johann 2006: Rente mit 67: Neue Herausforderungen für die Beschäftigungspolitik. IAB Kurzbericht 16/2006. Nürnberg

Gobeski, Kirsten T.; Beehr, Terry A. 2009: How retirees work: predictors of different types of bridge employment. In: Journal of Organizational Behavior 30,3: 401-425 [doi:10.1002/job.547].

Hank, Karsten 2004: Effects of Early Life Family Events on Women's Late Life Labour Market Behaviour. In: European Sociological Review 20,3: 189-198 [doi:10.1093/esr/ jch017].

Hank, Karsten 2011: How "Successful" Do Older Europeans Age? Findings From SHARE. In: The Journals of Gerontology Series B: Psychological Sciences and Social Sciences 66B,2: 230-236 [doi:10.1093/geronb/gbq089].

Heywood, John; Jirjahn, Uwe; Tsertsvardze, Georgi 2010: Hiring older workers and employing older workers: German evidence. In: Journal of Population Economics 23,2: 595-615 [doi:10.1007/s00148-008-0214-7].

Himmelreicher, Ralf K.; Hagen, Christine; Clemens, Wolfgang 2009: Bildung und Übergang in den Ruhestand: Gehen Höherqualifizierte später in Rente? In: Kölner Zeitschrift für Soziologie und Sozialpsychologie 61,3: 437-452 [doi:10.1007/s11577-009-0078-1].

Höhn, Charlotte; Mai, Ralf; Micheel, Frank 2008: Demographic Change in Germany. In: Hamm, Ingrid; Seitz, Helmut; Werding, Martin (Eds.): Demographic Change in Germany: The Economic and Fiscal Consequences. Berlin/New York: Springer: 9-33.

Kim, Jungmeen E.; Moen, Phyllis 2002: Retirement Transitions, Gender, and Psychological Well-Being: A Life-Course, Ecological Model. In: Journal of Gerontology: Psychological Sciences 57B,3: P212-P222.

Klein, Thomas; Unger, Rainer 2002: Aktive Lebenserwartung in Deutschland und in den USA. In: Zeitschrift für Gerontologie und Geriatrie 35,6: 528-539 [doi:10.1007/ s00391-002-0127-0].

Kohli, Martin 1985: Die Institutionalisierung des Lebenslaufs. Historische Befunde und theoretische Argumente. In: Kölner Zeitschrift für Soziologie und Sozialpsychologie 37,1: 1-29.

Komp, Kathrin; van Tilburg, Theo; van Groenou, Marjolein B. 2010: Paid work between age 60 and 70 years in Europe: a matter of socio-economic status? In: International Journal of Ageing and Later Life 5,1: 45-75 [doi:10.3384/ijal.1652-8670.105145].

Kruse, Andreas; Lehr, Ursula 1990: Psychologische Aspekte des Alterns. In: Späth, Lothar; Lehr, Ursula (Eds.): Altern als Chance und Herausforderung. Vol. 1. Stuttgart u.a.: Bonn aktuell: 80-96.

Künemund, Harald 2006: Tätigkeiten und Engagement im Ruhestand. In: Tesch-Römer, Clemens; Engstler, Heribert; Wurm, Susanne (Eds.): Altwerden in Deutschland. Sozialer Wandel und individuelle Entwicklung in der zweiten Lebenshälfte. Wiesbaden: VS Verlag für Sozialwissenschaften: 289-327. 
Lazear, Edward P. 1979: Why Is There Mandatory Retirement? In: Journal of Political Economy 87,6: 1261-1284

Lehr, Ursula 2000: Psychologie des Alterns. $9^{\text {th }}$ Edition. Wiebelsheim: Quelle \& Meyer.

Mai, Ralf 2003: Die Alten der Zukunft. Eine bevölkerungsstatistische Analyse. Schriftenreihe des Bundesinstituts für Bevölkerungsforschung 32. Opladen: Leske + Budrich.

Mayer, Karl Ulrich 2001: Lebensverlauf. In: Schäfers, Bernhard; Zapf, Wolfgang (Eds.): Handwörterbuch zur Gesellschaft Deutschlands. 2 ${ }^{\text {nd }}$ Edition. Opladen: Leske + Budrich: 446-460.

Moen, Phyllis 2003: Navigating Retirement and a New Life Stage. In: Mortimer, Jeylan T.; Shanahan, Michael J. (Eds.): Handbook of the Life Course. New York: Kluwer Academic/Plenum Publishers: 269-291.

Mor-Barak, Michál E. 1995: The meaning of work for older adults seeking employment: The generativity factor. In: The International Journal of Aging and Human Development 41,4: 325-344 [doi:10.2190/VGTG-EPK6-Q4BH-Q67Q].

Motel-Klingebiel, Andreas 2006: Materielle Lage älterer Menschen: Verteilungen und Dynamiken in der zweiten Lebenshälfte. In: Tesch-Römer, Clemens; Engstler, Heribert; Wurm, Susanne (Eds.): Altwerden in Deutschland. Sozialer Wandel und individuelle Entwicklung in der zweiten Lebenshälfte. Wiesbaden: VS Verlag für Sozialwissenschaften: 155-230.

O'Reilly, Patrick; Caro, Francis G. 1995: Productive Aging: An Overview of the Literature. In: Journal of Aging \& Social Policy 6,3: 39-71 [doi:10.1300/J031v06n03_05].

Pengcharoen, Chanjira; Shultz, Kenneth S. 2010: The influences on bridge employment decisions. In: International Journal of Manpower 31,3: 322-336 [doi:10.1108/0143772 1011050602].

Pienta, Amy M.; Hayward, Mark D. 2002: Who Expects to Continue Working After Age 62? The Retirement Plans of Couples. In: The Journals of Gerontology Series B: Psychological Sciences and Social Sciences 57,4: S199-S208 [doi:10.1093/geronb/57.4.S199].

Pleau, Robin L. 2010: Gender Differences in Postretirement Employment. In: Research on Aging 32,3: 267-303 [doi:10.1177/0164027509357706].

Radl, Jonas 2007: Individuelle Determinanten des Renteneintrittsalters. Eine empirische Analyse von Übergängen in den Ruhestand. In: Zeitschrift für Soziologie 36,1: 43-64.

Rhein, Thomas 2010: Ist Europa auf dem Weg zum „Turbo-Arbeitsmarkt"? Beschäftigungsdynamik im internationalen Vergleich. IAB Kurzbericht Nr. 19. Nürnberg.

Ruhm, Christopher J. 1990: Determinants of the timing of retirement. In: Doeringer, $P e-$ ter $B$. (Eds.): Bridges to retirement. Older workers in a changing labor market. Ithaca, NY: ILR Press School of Industrial and Labor Relations Cornell University: 23-32.

Schmidt, Tanja; Schmitt, Christoph 2005: Erwerbsverläufe. In: Soziologisches Forschungsinstitut (SOFI) et al. (Eds.): Berichterstattung zur sozioökonomischen Entwicklung in Deutschland. Arbeit und Lebensweisen. Erster Bericht. Wiesbaden: VS Verlag für Sozialwissenschaften: 303-322.

Shacklock, Kate; Brunetto, Yvonne; Nelson, Silvia 2009: The different variables that affect older males' and females' intentions to continue working. In: Asia Pacific Journal of Human Resources 47,1: 79-101 [doi:10.1177/1038411108099291].

Siegrist, Johannes; Wahrendorf, Morten; dem Knesebeck, Olaf von; Jurges, Hendrik; Borsch-Supan, Axel 2007: Quality of work, well-being, and intended early retirement of older employees-baseline results from the SHARE Study. In: European Journal of Public Health 17,1: 62-68 [doi:10.1093/eurpub/ckl084]. 
Smith, Deborah B. 2004: Volunteering in Retirement: Perceptions of Midlife Workers. In: Nonprofit and Voluntary Sector Quarterly 33,1: 55-73 [doi:10.1177/08997 64003260591].

Statistisches Bundesamt 2009: Bevölkerung Deutschlands bis 2060 - Ergebnisse der 12. koordinierten Bevölkerungsvorausberechnung. Wiesbaden.

Szinovacz, Maximiliane E. 2003: Contexts and Pathways: Retirement as Institution, Process, and Experience. In: Adams, Gary A.; Beehr, Terry A. (Eds.): Retirement. Reasons, processes, and results. New York: Springer: 6-52.

Tabachnick, Barbara G.; Fidell, Linda S. 2007: Using Multivariate Statistics. $5^{\text {th }}$ Edition Boston: Allyn and Bacon.

Talaga, Jean A.; Beehr, Terry A. 1995: Are There Gender Differences in Predicting Retirement Decisions? In: Journal of Applied Psychology 80,1: 16-28 [doi:10.1037/00219010.80.1.16].

Taylor, Mary A.; Doverspike, Dennis 2003: Retirement Planning and Preparation. In: $A d$ ams, Gary A.; Beehr, Terry A. (Eds.): Retirement. Reasons, processes, and results. New York: Springer: 53-82.

Tews, Hans P. 1996. In: Baltes, Margret; Montada, Leo (Eds.): Produktives Leben im Alter. Frankfurt am Main u.a.: Campus Verlag: 184-210.

van Dam, Karen; van der Vorst, Janine D.M.; van der Heijden, Beatrice I.J.M. 2009: Employees' Intentions to Retire Early. In: Journal of Career Development 35,3: 265-289 [doi:10.1177/0894845308327274].

Wang, Mo 2007: Profiling Retirees in the Retirement Transition and Adjustment Process: Examining the Longitudinal Change Patterns of Retirees' Psychological Well-Being. In: Journal of Applied Psychology 92,2: 455-474 [doi:10.1037/0021-9010.92.2.455].

Wang, Mo; Shultz, Kenneth S. 2010: Employee Retirement: A Review and Recommendations for Future Investigation. In: Journal of Management 36,1: 172-206 [doi:10.1177/0149206309347957].

Wübbeke, Christina 2005: Der Übergang in den Rentenbezug im Spannungsfeld betrieblicher Personal- und staatlicher Sozialpolitik. Textband und Anhangband. Beiträge zur Arbeitsmarkt- und Berufsforschung 290. Nürnberg.

Zhan, Yujie; Wang, Mo; Liu, Songqi; Shultz, Kenneth S. 2009: Bridge Employment and Retirees' Health: A Longitudinal Investigation. In: Journal of Occupational Health Psychology 14,4: 374-389 [doi:10.1037/a0015285]

Translated from the original text by the Federal Institute for Population Research, for information only. The reviewed and author's authorised original article in German is available under the title "Die Bereitschaft zur Weiterbeschäftigung im Ruhestandsalter im Zusammenhang mit sozioökonomischen Merkmalen", DOI 10.4232/10.CPoS-2010-19de or URN urn:nbn:de:bib-cpos-2010-19de6, at http://www.comparativepopulationstudies.de.

Frank Micheel $(\varangle)$, Ines Wickenheiser. Federal Institute for Population Research,

Wiesbaden, Germany. E-Mail: frank.micheel@destatis.de, ines.wickenheiser@destatis.de URL: www.bib-demografie.de

Dr. Juliane Roloff. E-Mail: juliane.roloff@gmx.de 


\section{Comparative Population Studies - Zeitschrift für Bevölkerungswissenschaft}

wWw.comparativepopulationstudies.de

ISSN: 1869-8980 (Print) - 1869-8999 (Internet)

Published by / Herausgegeben von

Prof. Dr. Norbert F. Schneider

Layout and print: Federal Institute for Population Research, Wiesbaden (Germany)

Managing Editor / Redaktion

Frank Swiaczny

\section{Copy Editor / Schlussredaktion}

Dr. Evelyn Grünheid

\section{Scientific Advisory Board / Wissenschaftlicher Beirat}

Jürgen Dorbritz (Wiesbaden)

Paul Gans (Mannheim)

Johannes Huinink (Bremen)

Marc Luy (Wien)

Clara H. Mulder (Groningen)

Notburga Ott (Bochum)

Peter Preisendörfer (Mainz)

\section{Board of Reviewers / Gutachterbeirat}

Martin Abraham (Erlangen)

Laura Bernardi (Lausanne)

Hansjörg Bucher (Bonn)

Claudia Diehl (Göttingen)

Andreas Diekmann (Zürich)

Gabriele Doblhammer-Reiter (Rostock)

Henriette Engelhardt-Wölfler (Bamberg)

E.-Jürgen Flöthmann (Bielefeld)

Alexia Fürnkranz-Prskawetz (Wien)

Beat Fux (Zürich)

Joshua Goldstein (Rostock)

Karsten Hank (Köln)

Sonja Haug (Regensburg)

Franz-Josef Kemper (Berlin)

Michaela Kreyenfeld (Rostock)

Aart C. Liefbroer (Den Haag)

Kurt Lüscher (Konstanz)

Dimiter Philipov (Wien)

Tomáš Sobotka (Wien)

Heike Trappe (Rostock) 